\title{
7 Economic consequences of globalisation: case study of Thailand
}

\author{
Archanun Kohpaiboon and \\ Juthathip Jongwanich
}

\section{Introduction}

The net benefits of economic globalisation are a subject of heated debate (Bhagwati, 2004; Wolf, 2005; Irwin, 2015). ${ }^{1}$ Since the new millennium, antiglobalisation has grown stronger, reflecting cases where applied tariff rates have been raised, as well as non-tariff measures such as anti-dumping. In reality, economic globalisation has the potential to bring numerous benefits, making a systematic literature survey necessary.

Thailand was classified by Sachs and Warner (1995: Table 1) as always open since 1940, together with Barbados, Cyprus, Hong Kong, Malaysia, Mauritius, Singapore, and Yemen Arab Republic. This is supported by Thailand being one of the production hubs of multinational enterprises (MNEs) (Kohpaiboon, 2008; Kohpaiboon and Jongwanich, 2013). This would seem to run counter to Thailand's maintaining a relatively high tariff by regional standards. The unweighted average tariff of Thailand is relatively high compared with six original ASEAN members. In addition, the story of Thai automotives is often claimed as a success of government intervention, local content requirements (LCRs), and high cross-border protection. Against this backdrop, the paper reviews empirical works using Thailand as a case study.

The paper is organised as follows: Section 2 presents policies regarding the global integration of the Thai economy, particularly regarding trade, foreign direct investment, and labour mobility. In Section 3, growth and industrial transformation are described in order to raise concerns about economic consequences of globalisation, which will be used for in-depth discussion in the following section (Section 4: Economic Consequences). Conclusions and policy lessons are in the final section.

\section{Policies and global integration of Thailand}

From 1960 onward, the Thai government has maintained a firm commitment to private sector industrialisation combined with prudent public investment in infrastructure. Influenced by the World Bank in the late 1950s, government 
involvement shifted from direct production via state enterprises towards investment in public infrastructure required for economic development, such as electricity, water supply, and transportation facilities. The government virtually prohibited state participation in those commercial and industrial activities that might be expected to compete directly with private capital (Suehiro, 1989: 180).

This is associated with a 'market-friendly' approach towards foreign investors. There have not been any major policies preventing foreign investors from being involved in almost any business. This is especially true for the manufacturing sector, where foreign investors are usually guaranteed the same rights as domestic investors. There are guarantees against expropriation and nationalisation; further, the government permits remitting investment capital, profits, and other payments in any foreign currency. Despite the presence of capital control measures during the pre-1990 period, in practice, repatriation of foreign capital related to direct investment (e.g. investment capital, profit or dividends, interest and principal of foreign loans, royalties and payments on other obligations) has not been restricted (Suehiro, 1989: 179).

There have been restrictions on land ownership and hiring of foreign migrants by foreign investors. In general, according to the Land Code (1954), foreignowned firms are not allowed to own land. ${ }^{2}$ According to the Alien Occupation Law, passed in 1973 and amended in 1978, foreigners require a work permit. Such restrictions have not been prohibitive. They have not applied to foreigners who received investment privileges from the Thai Board of Investment (BOI). This restriction was abolished in 2000 for the manufacturing sector.

This trade policy regime influences firms' market orientation, as well as the speed of global integration of firms in Thailand. While Thailand also established the BOI to grant investment incentives and privileges to industries targeted by the government, its effectiveness remains unclear (Kohpaiboon, 2006a); at best, it has been complementary to the trade policy regime (Kohpaiboon, 2006; Kohpaiboon and Jongwanich, 2014).

Trade policy in Thailand heavily relies on tariff measures, whereas non-tariff measures (NTMs) and quantitative restrictions have been imposed on few products and agricultural items (World Trade Organization WTO, 2015). ${ }^{3}$ The only exception was the automotive industries, which have been the main interest to the Ministry of Industry. There were government efforts that were first implemented in the mid-1970s (i.e. imposing local content requirement to carmakers) up to the new millennium (Kohpaiboon, 2006).

Between the 1960s and the mid-1980s, Thailand's escalating tariff structure was tilted towards the highest rate associated with finished products, as opposed to the lowest rate associated with raw materials. This structure was to promote an importsubstitution strategy, with relatively high tariff levels, together with a cascading structure tending to alter relative prices in favour of producing goods for the domestic market, instead of targeting exports. The average unweighted mostfavoured nation rate was $41.2 \%$ by 1986. As shown in Figure 7.1, the degree of openness, that is, the sum of export and import of goods and services as a percentage of gross domestic product (GDP), was around $40 \%-50 \%$. To eliminate 


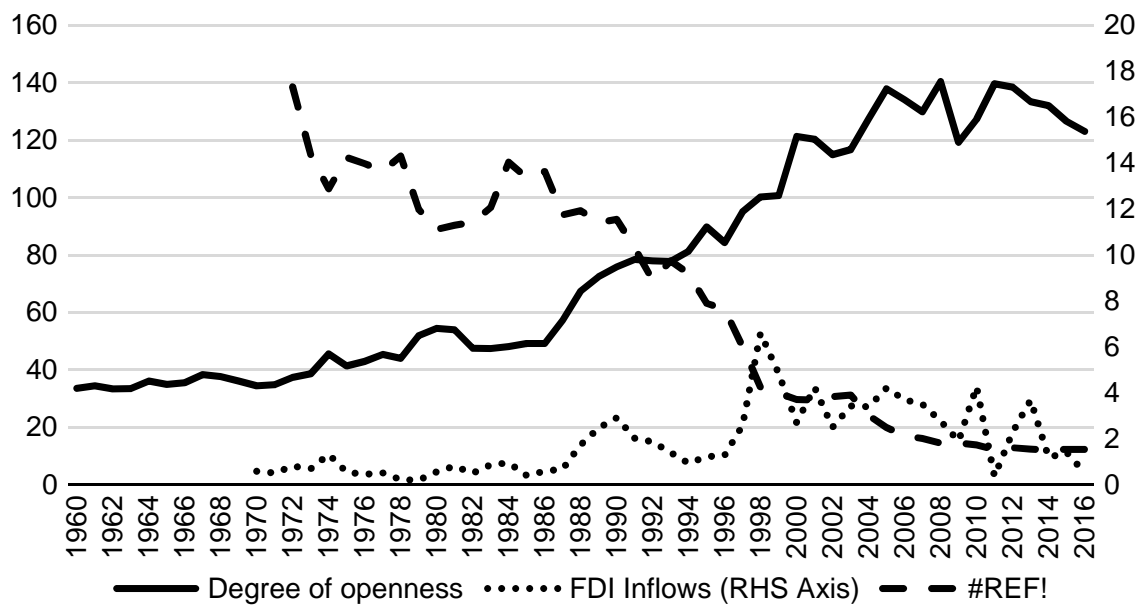

Figure 7.1 Global Integration of Thailand between 1960 and 2017.

Source: Degree of openness is from World Development Indicator whereas FDI inflows from. Note: Unit $=\%$ of GDP. FDI $=$ foreign direct investment.

excess supply in the domestic market, exports during this period were dominated by agricultural raw materials.

A similar pattern was observed with inflows of FDI, whose annual rates varied between US\$100 and $\$ 400$ million over the considered period, accounting for around $0.5 \%$ of GDP (Figure 7.1). FDI inflows were dominated by tariffhopping ones (Kohpaiboon, 2006).

While tariff levels remained virtually unchanged with few exceptions from 1983 to the mid-1990s, various exemption schemes promoted Thailand as an export platform for multinationals (Kohpaiboon, 2006; Jongwanich and Kohpaiboon, 2007). By 1990, the average unweighted most-favoured-nation rate remained at around $40 \%$. Domestic firms can be export-oriented and apply available exemption schemes in order to mitigate any of the adverse effects of input tariffs. The effectiveness of the exemptions was reflected by the declining tariff incidence and the percentage of tariff revenue to total imports, most noticeably between the mid1980s and the early 1990s. These exemption schemes and one introduced by the BOI have been intensively used since then. As argued in Kohpaiboon and Jongwanich (2019), exemption schemes accounted for $45 \%$ of total imports in 2012.

As result, the degree of openness of Thailand increased dramatically, increasing to $89.8 \%$ in 1995 . It was associated with influx of FDI inflows, whose annual rates rose more than fivefold to over US $\$ 2$ billion and remained at roughly these levels over the next eight years. This is in line with Bhagwati's 1985 hypothesis that an export-oriented industrialisation (EOI) strategy is likely to both attract more FDI and promote its more efficient utilisation than import substitution. ${ }^{4}$ 
In the 1990s, when the Thai government experienced substantial improvements in its fiscal position, tariff reform was undertaken. In particular, tariff bands were cut from 39 to six $(0 \%, 1 \%, 5 \%, 10 \%, 20 \%$, and $30 \%)$. Nonetheless, there were substantial exemptions whose tariffs were greater than $30 \%$. As a result, the simple tariff average dropped substantially from $40 \%$ in the mid-1980s to $17 \%$ in 1997. Tariff restructuring received renewed emphasis in the new millennium with an ambitious target of three tariff bands, i.e. $0 \%-1 \%$ for raw materials, $5 \%$ for intermediates, and 10\% for finished products. It began in June 2003. The magnitude of such reduction was moderate and focused on intermediate tariffs. As a result, the average tariff dropped to $8.7 \%$ by 2011 . Nonetheless, nearly onefifth of tariff lines had rates greater than 20\% in 2004-08 (Table 7.1).

By the standard of developing countries in the region, Thailand's tariff rate is relatively high (Table 7.2). In particular, the average tariff of Thailand was higher than Malaysia (5.3\% in 2012), the Philippines (6.2\% in 2011), and Indonesia $(6.6 \%$ in 2012$)$. The weighted average was much lower than the unweighted, implying that tariffs imposed on certain products are redundant. In some products such as vehicles and clothing, tariffs are still very high, that is, $30 \%$ and $80 \%$, respectively. In addition, the tariff structure remains escalating in spite of the lower tariff protection.

In the new millennium, political attention and negotiating resources in Thailand have been shifted towards preferential trade agreements and bilateral free trade accords (FTAs). This was driven by various factors such as the slowdown in WTO liberalisation negotiations, and the political re-entry by Thaksin Shinawatra and his newly found political party Thai Rak Thai (Kohpaiboon and Jongwanich, 2019). As a result, there were 18 FTAs signed with partners including ASEAN members, Japan, Republic of Korea, China, Australia, New Zealand, India, Chile, and Peru, many of which have more than one FTA in effect. Note that only eight FTAs involve substantial tariff cuts, covering more than $80 \%$ of tariff lines and having been offered since 2010. These include the ASEAN Free Trade Area (now known as ASEAN Economic Community),

Table 7.1 Share of Four-Digit HS Categories of Applied Tariff Rates in Thailand, 1989-2008

\begin{tabular}{llllll}
\hline Tariff Bands & 1989 & 1995 & 2002 & 2003 & $2004-08$ \\
\hline 0 & 2.5 & 2.6 & 5.6 & 5.7 & 6.0 \\
$0.1-5$ & 14.4 & 17.3 & 33.3 & 37.7 & 48.8 \\
$5.1-10$ & 14.2 & 17.6 & 14.1 & 14.2 & 14.8 \\
$10.1-15$ & 12.7 & 3.2 & 3.9 & 4.5 & 3.6 \\
$15.1-20$ & 15.4 & 16.4 & 21.4 & 17.9 & 8.4 \\
$20.1-30$ & 15.8 & 16 & 13.8 & 14.3 & 12.7 \\
$30-100$ & 25 & 26.8 & 7.8 & 5.8 & 5.7 \\
\hline
\end{tabular}

Source: Data for 1989 and 1995 from World Trade Organization (1990; 1995), respectively. Data for 2002-08 are from authors' compilation from official document provided by Ministry of Finance.

HS = Harmonized Commodity Description and Coding Systems. 
Table 7.2 Weighted Average of Most-Favoured-Nation Tariff Rate of Selected Countries during 2010-12

\begin{tabular}{lllll}
\hline Country (Year) & Unweighted & Weighted & $\begin{array}{l}\text { Agricultural } \\
\text { Products }\end{array}$ & $\begin{array}{l}\text { Non-agricultural } \\
\text { Products }\end{array}$ \\
\hline Thailand (2011) & 8.7 & 5.0 & 9.0 & 4.9 \\
Vietnam (2010) & 9.8 & 12.2 & 24.4 & 10.7 \\
Singapore (2011) & 0.0 & 0.0 & 0.0 & 0.0 \\
Philippines & 6.2 & 12.2 & 23.2 & 10.4 \\
$\quad$ (2011) & & & & \\
Myanmar (2011) & 5.6 & 6.6 & 12.6 & 4.9 \\
Malaysia (2012) & 5.3 & 6.7 & 8.7 & 6.5 \\
Indonesia (2012) & 6.6 & 9.8 & 1.8 & 11.1 \\
Lao PDR (2008) & 9.7 & 13.6 & 19.3 & 12.6 \\
Brunei & 2.5 & 1.7 & 0.0 & 2.6 \\
Darussalam & & & & \\
(2011) & & & & 11.1 \\
Cambodia (2012) & 10.9 & 12.0 & 14.7 & 3.9 \\
Australia (2011) & 2.8 & 3.8 & 1.6 & 2.8 \\
New & 2.0 & 2.7 & 1.9 & 7.4 \\
Zealand (2011) & & & & 7.7 \\
China (2010) & 9.9 & 8.6 & 21.5 & 1.3 \\
India (2012) & 13.3 & 9.4 & 48.6 & 5.6 \\
Japan (2011) & 3.0 & 2.1 & 7.0 & \\
Republic of & 11.2 & 9.6 & 34.1 & \\
Korea (2011) & & & & \\
\hline
\end{tabular}

Source: Author's calculation using most-favoured-nation tariff rates from the World Trade Organization.

Lao PDR = Lao People's Democratic Republic.

ASEAN-China FTA, the Thailand-Australia FTA, the Thailand-New Zealand FTA, the Japan-Thailand Economic Partnership Agreement, the ASEAN-Japan FTA, the ASEAN-Korea FTA, and the ASEAN-Australia-New Zealand FTA. In the other three FTAs (i.e. the Thailand-Peru FTA, the Thailand-Chile FTA, ASEAN-India FTA), substantial tariff cuts took place in 2015 and 2016 (Kohpaiboon and Jongwanich, 2019).

Interestingly, commitments made in these FTAs focus on goods market liberalisation. The commitments that Thailand made on other issues under these FTAs, except in the case of the ASEAN Economic Community, were rather weak and at most in line with WTO commitments. This is especially true for FTAs that Thailand has with developing country FTA partners. As argued in Kohpaiboon and Jongwanich (2019), Thailand was reluctant to offer tariff cuts in these FTAs in terms of product coverages and long-time schedules of implementation. On the import side, therefore, tariff cuts under FTAs might not induce any substantial trade enhancing effect from FTA partners to Thailand.

FTAs ensure firms in Thailand are not in a disadvantageous position with respect to accessing partner markets. This would maintain Thailand's attractiveness for export-oriented FDI. It seems that this strategy has been partially 
successful as the use of FTAs in terms of exports was highly concentrated between 2006 and 2015 (Jongwanich and Kohpaiboon, 2017; Kohpaiboon and Jongwanich, 2019). To a certain extent, it is a testament to the increasing openness of the Thai economy. Nonetheless, the evidence supporting the idea that the FTAs attracted FDI is rather weak. As shown in Figure 7.1, FDI as a percentage of GDP exhibited a downward trend from 2005 onward. In addition, there was no clear correlation between bilateral FDI inflows before and after signing FTAs in most of the partners documented in Kohpaiboon and Jongwanich (2019).

Until the new millennium, trade and FDI were the main driver of economic globalisation in Thailand. Since then, labour mobility has played an increasing role. In the past, Thailand was a net labour exporter, with many Thais working in the Middle East. Nonetheless, the number of these workers was rather small, as reflected in the negligible share of remittances in total export earnings from the 1970s to the 1990s. The tightening labour market in Thailand and the economic development gap with neighbouring countries in mainland Southeast Asia caused an influx of workers from elsewhere in the region (Figure 7.2). The number of total foreign workers in Thailand increased from 0.17 to 2 million between 2006 and 2017. Note that such official figures tend to be underestimated; for example, Bylander and Reid (2017) claimed the figure exceeded 4 million. This size is double the official figure, giving a rough size of the underestimation of the official figure.

\section{5}

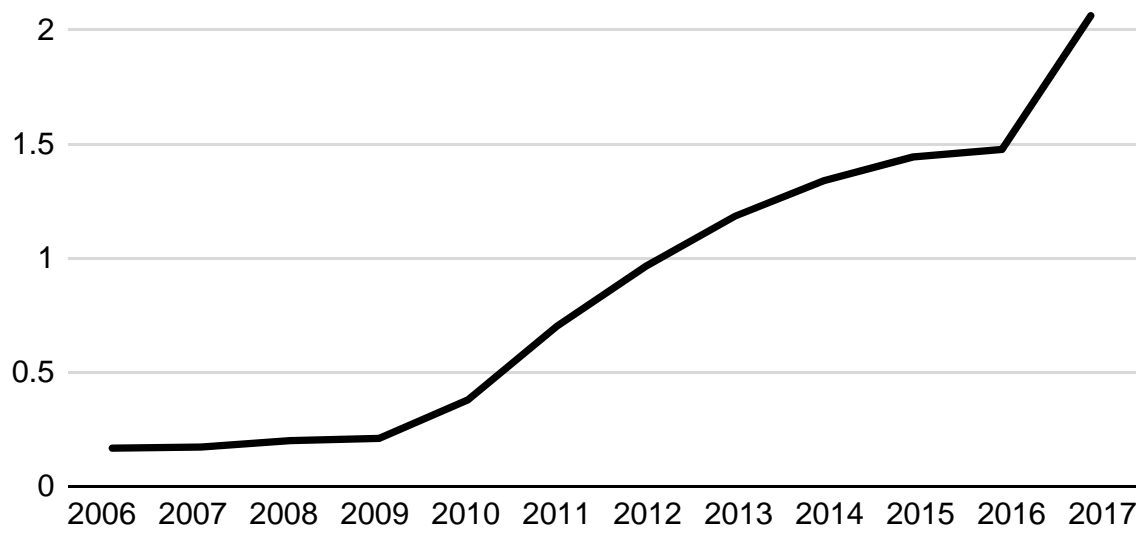

Figure 7.2 Number of Foreign Workers from 2006 to 2017.

Source: Author compilation from Department of Employment, Ministry of Labor, Thailand, available at https://www.doe.go.th/prd/alien/statistic/param/site/ $152 /$ cat/82/sub/74/pull/sub_category/view/list-label.

Note: Unit $=$ million workers. 
Despite starting in the late 1980s, the policy stance of the Thai government has been clearer in the new millennium where the need for foreign workers was evident. The policy stance was shifted towards managing these workers while avoiding permanent settlement and any potential adverse effects, such as a rising demand for public services, a reduction in social cohesion, and other negative social effects. Hence, a new registration system was introduced in 2004. It is worth noting that under the new registration, firms are allowed to temporarily hire illegal foreign workers, but must bring them to be registered with the Ministry of Labor to identify their true nationality. While waiting for nationality identification to be completed, these workers are allowed to work at a given firm and in a given location (i.e. province). Nonetheless, illegal migrant problems remain as a result of regulatory cumbersome involving in nationality. Given the number of immigrants in Thailand, labour mobility will be another driver of economic globalisation for the next decade.

\section{Growth and industrial transformation}

From 1960 to 1985 , the import substitution undermined the domestic incentive structure and favoured those industries over export-oriented ones. As a consequence, the Thai economy began to grow rapidly from the 1960s through the mid-1970s. The annual growth rate during the considered period averaged $7.5 \%$ (Figure 7.3). As expected, the share of the manufacturing sector to GDP rapidly increased from $11.6 \%$ in the 1950 s to $14.2 \%$ and $18.6 \%$ during the 1960 s and the first half of the 1970s, respectively (Figure 7.3).

As argued in Krueger (1992: 43-4), rapid expansion of import-substituting industries is typically short lived, after the easy opportunities (meeting domestic demand

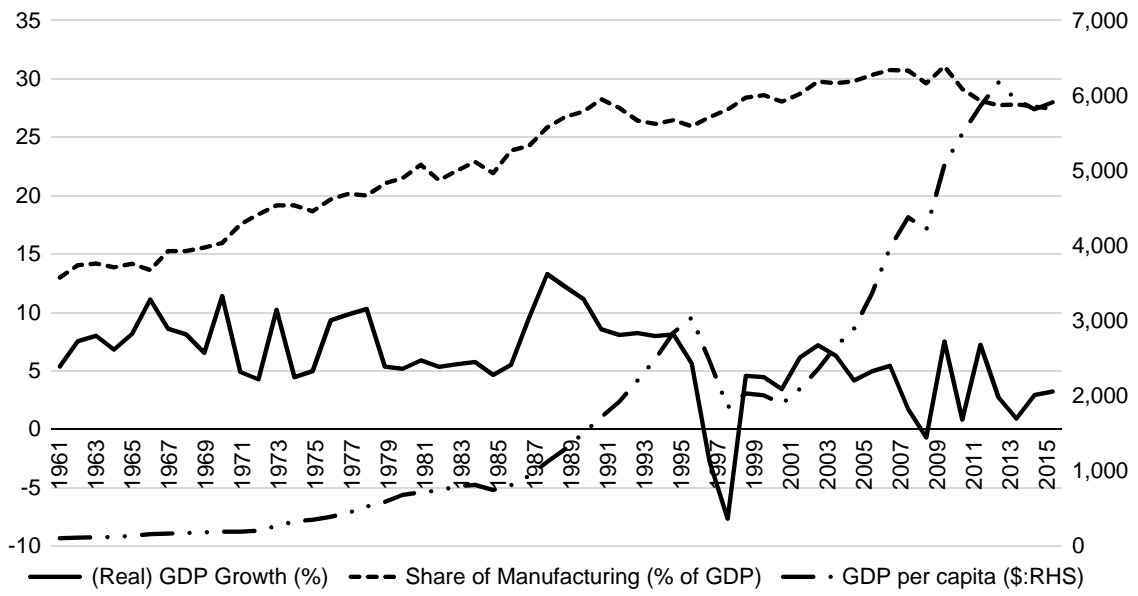

Figure 7.3 Growth and Industrialisation in Thailand.

Source: World Development Indicator database.

Note: GDP $=$ gross domestic product. 
in textiles, footwear, some food processing, and other light labour-intensive activities) are exhausted. In Thailand, the easy import substitution opportunities included textiles and clothing, transport equipment, basic metal industries, and chemical products. In the textile industries where there is a wide range of production technology involved, from capital-intensive, i.e. synthetic fibres, to labour-intensive, i.e. fabrics, production took place in the most labour-intensive segment, i.e. the shuttle-loom weaving industry (Suehiro, 1989; Kohpaiboon, 1995). Similarly, the Thai automotive industry began with local manufacture of bulky, simple, and quasi non-tradable parts, whereas it was heavily reliant on imports of complicated parts, especially engines (Kohpaiboon, 2006).

Since then, new import-substituting activities were associated with higher investment costs so that manufacturing growth bottomed out in 1985. The average annual growth of GDP dropped noticeably to $5 \%$ during the period 1981-85. The manufacturing share in the GDP remained more or less the same at around $22 \%$ between 1976 and 1985. Import-substituting industries did not contribute significantly to employment (Figure 7.3).

Between 1970 and 1985, manufacturing employment accounted for only $8.2 \%$ of total employment. The employment share of the manufacturing sector increased from $4.5 \%$ in 1970 to around $8.4 \%$ in 1975 and then remained more or less unchanged at this level during the following decade ending in 1985. Figure 7.4

Another undesirable consequence of pursuing an import substituting industrialisation strategy is that local manufacturing was heavily reliant on imported intermediate goods. Thus, the successive balance of payment deficits

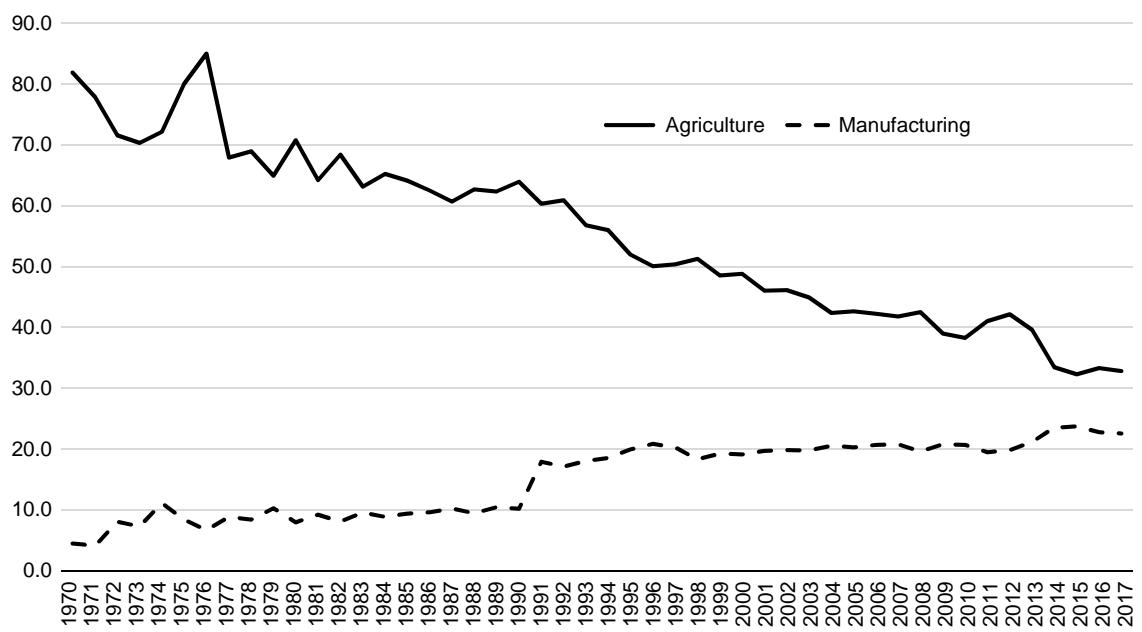

Figure 7.4 Employment Structure in Thailand from 1970 to 2017.

Source: World Development Indicator Database.

Note: Unit $=\%$ to GDP. 


\section{2}

between the late 1970s and the early 1980s gradually caused the government to shift the industrialisation strategy to favour exports. As mentioned above, the main instrument was the tariff exemption scheme by BOI that partly mitigated the adverse impact of input tariffs on the international competitiveness of exportoriented industries (Suehiro, 1989: 270).

Two favourable factors in promoting exports of Thai manufacturing were interplaying. The first factor was a series of currency devaluations during the first half of the 1980s to improve external imbalances (Warr and Nidhiprabha, 1996: 206). In particular, the baht was devalued by around $36 \%$ in 1985 . The second favourable factor was that East Asian investors were seeking an export base abroad to maintain their international competitiveness in labour-intensive products in the mid-1980s. The erosion of their home countries' international competitiveness was the outcome of wage increases and currency appreciation in the mid-1980s. In addition, the imposition and gradual tightening of quantitative restrictions by developed countries constrained certain labour-intensive exports, mostly textiles, garments, and footwear, from these East Asian exporters (Wells, 1986). In the electronics industry and other durable consumer goods industries, technological innovations began to allow these investors to slice up the value chain of their production, relocating labour-intensive segments rather than entire industries to benefit from cheap labour available abroad (Krugman, 1995).

As a result, manufacturers from Japan and the Northeast Asian Newly Industrialized Economies (NIEs) have become actively involved with outward direct investment and have established a regional network to strengthen their international competitiveness. Thailand was selected by these investors to be their labour-intensive export base and rapidly integrated into global production sharing (GPS) of multinationals around the world (Kohpaiboon, Jongwanich, and Kulthanavit, 2012; Kohpaiboon and Jongwanich, 2013).

After shifting towards an EOI strategy around the mid-1980s, the economy experienced a rapid growth. Manufacturing export growth increased from 11.1\% in the first half of the 1980 s to $40.5 \%$ and $18 \%$ during the periods $1986-90$ and 1991-96, respectively. The average annual growth of manufacturing output jumped to $15.1 \%$ and declined slightly to $10.5 \%$ during the same periods, respectively (Figure 7.3). As a result, the share of the manufacturing sector in GDP increased from $22 \%$ in the first half of the 1980 s to $27 \%$ in the decade ending in 1996. The annual economic growth rate between 1988 and 1996 averaged out at $9.3 \%$. This was a classic example of the export-led growth phenomenon.

As documented in Kohpaiboon (2006), EOI began with labour-intensive manufacturing industries such as clothing, footwear, leather products, furniture, toys, jewels and gems, and electronics (Table 7.3). While capital-intensive industries figured prominently among the declining sectors, transportation equipment retained its share. The expansion of such labour-intensive manufactured products increased importance for the sector not only in terms of export earnings, but also in terms of employment absorption, with its share increasing to $13.6 \%$ and $15.1 \%$ in $1991-95$ and $1996-2000$, respectively, from around $8 \%$ 


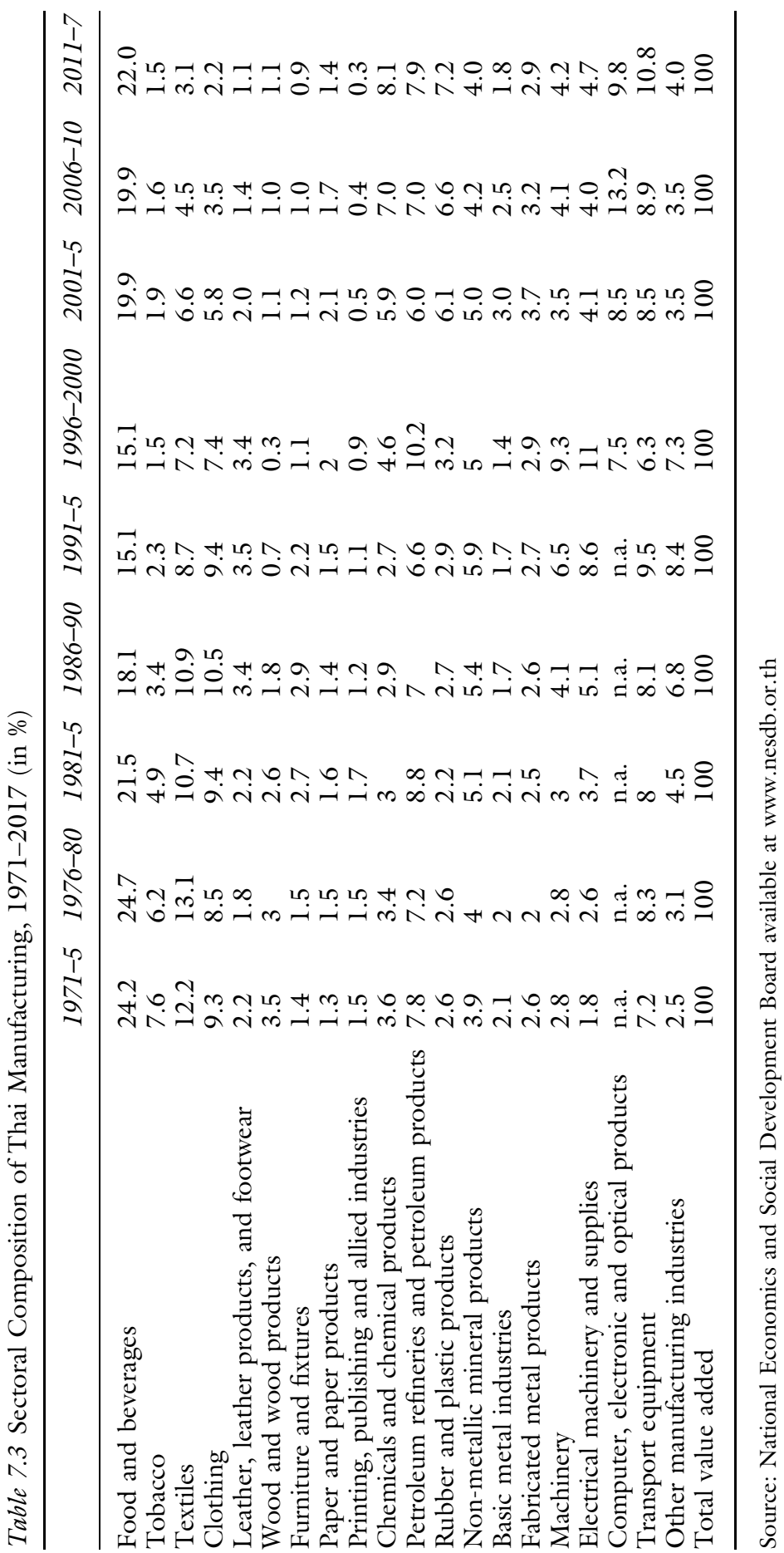




\section{Archanun Kohpaiboon \& Juthathip Jongwanich}

during the period 1970-85 (Figure 7.3). Nevertheless, its performance in employment absorption seemed to be far from satisfactory. More than $50 \%$ of employed workers are still in the agricultural sector, whose income share is around $10 \%$.

The high-growth performance ended in 1997 when the country experienced the financial crisis. The economic growth dropped dramatically to -1.4 and $-10.5 \%$ in 1997 and 1998, respectively. The economy, nonetheless, recovered gradually and achieved an annual growth rate of $7 \%$ by 2003 . The model simulation in Jongwanich (2007) pointed to the capital account opening that was speeded up in the early 1990s as the main cause of the 1997-98 crisis. It seemed inevitable that the boom fuelled by non-FDI capital inflows should not go on under a more flexible exchange rate regime.

Although the dramatic currency depreciation during the onset of the crisis should have been the catalyst for a manufacturing export boom, manufacturing exporters were restrained by the credit crunch in the financial sector. Until 1999, manufacturing export growth resumed. By contrast, FDI inflows increased rapidly after the currency depreciation, referred to as fire-sale FDI in Krugman (2000). Even though there was substantial merger and acquisition FDI during the onset of the crisis, greenfield FDI accounted for more than 50\% of total inflows.

Since the Asian financial crisis, Thailand experienced a slight growth slowdown between 2000 and 2005. The annual growth rate during this period was around $5.3 \%$ on average. It has worsened since 2006 , with both internal and external factors interplaying. These included political unrest starting in 2005, the sickness of King Rama IV from 2006 to 2016, the 2011 Great Floods, the deteriorating global situation (e.g. the global financial crisis beginning in 2008, Brexit, the European crisis, and the trade war between the US and China starting in 2018). Nonetheless, such a slow growth episode after the financial crisis is often claimed as the symbol of the middle-income trap in Thailand (e.g. Warr, 2011; Jitsuchon, 2012; Bisonyabut and Kamsaeng, 2015; Tangkitvanich and Bisonyabut, 2015; and World Bank, 2016). Many believe that it is an economic consequence of global integration of Thailand and that of the export-led growth model adopted through EOI strategy. As presented in the latest country's diagnostic report in 2016 by World Bank, causes of growth slowdown are listed below:

- Fail to sustain strong productivity-driven growth;

- Losing export competitiveness in labour-intensive manufacturing;

- Unsuccessful upgrading to sophistication of Thailand's medium and hightech exports; and

- Limited FDI spillovers and slump of private investment (World Bank, 2016).

Whether the causes of growth slowdown listed are economically sound remains debatable, but these causes were well taken into Thailand's policy-making as reflected in the report prepared by Dr. Kanit Sangsubhan for Prime Minister in 
17 November 2015 (Private Investment Promotion Working Group, 2015). This report resulted in the Thailand 4.0 Policy, the latest economic policy flagship of Gen Prayuth's administration (2014-the present) to transform the economy. In the plan, 10 industries are selected as new engines of growth. They are divided into two segments, five S-curved and five new S-curved industries. The former are existing industrial sectors, which will be improved through technological uptake. They include new-generation automotives, smart electronics, tourism, agriculture, and biotechnology. The latter are manufacturing robotics, medical hub, aviation and logistics, biofuels and biochemicals, and digital, all of which are slated to become significant long-term growth drivers.

To achieve the industrial transformation above, the Eastern Economic Corridor (EEC) special economic zone was established. The EEC straddles three eastern provinces - Chonburi, Rayong, and Chachoengsao - off the coast of the Gulf of Thailand and spans a total of 13,285 square kilometres. The government hopes to complete the EEC by 2021 , turning these provinces into a hub for technological manufacturing and services with strong connectivity to its ASEAN neighbours by land, sea, and air. On 1 February 2018, the Thai parliament approved the law for trade and investment in the EEC. The government of Thailand expects US $\$ 43$ billion of investment will be channelled into the EEC by 2021, from state funds, FDI, and through infrastructure development under a public-private partnership framework. An estimated 100,000 new jobs will be created as a result.

Despite the effort to target certain industries, there have not been any concrete policies to alter private sector industrialisation starting in the 1960s. To a large extent, the EEC project is similar to the Eastern Seaboard project launched in the mid-1980s, where investment incentives were offered to invite FDI, together with enlarging capability in supplying physical infrastructure services.

\section{Economic consequences}

As discussed in the previous section, debate on economic consequences of globalisation seems to be a recent phenomenon after the 1997-98 Asian financial crisis. In this section, the causes of growth slowdown mentioned in World Bank (2016) can be addressed in four aspects.

\subsection{Trade and productivity}

One favourable consequence of economic globalisation is that opening up to international trade could foster productivity growth. Productivity gains arising from the development of neoclassical international trade have been studied for several decades. Such gains are derived from resource reallocation from sectors in which the country has a comparative disadvantage to those in which it holds a comparative advantage driven by either technology, resource endowment, or both. This reallocation improves productivity at the aggregate level, despite the fact that individual firms' productivity remains unchanged. In addition, 
international trade can act as a channel for advanced technology developed elsewhere to be transmitted to a country in interest. Pioneered by Melitz (2003), firm heterogeneity suggests that international trade might have different effect in a given industry, driving better-performing ones to expand into larger markets, and stimulating resource reallocation. This, therefore, leads to productivity improvement, despite the fact that individual firms' productivity remains unchanged. The key inference is in favour of pursuing trade liberalisation.

The empirical studies examining the effect on trade liberalisation in Thailand were found in both aggregate and plant-level data analysis. The sample of the former includes Urata and Yokota (1994), Kohpaiboon (2003), Diao, Rattso, and Stokke (2006), and Phoonichaisuk (2010). Note that only Urata and Yokota (1994) directly addressed the effect of trade liberalisation on total factor productivity. Diao Rattso, and Stokke (2006) examined it by undertaking the model simulation- The other two studies empirically examined the effect of FDI on growth, with export-output being introduced as one of explanatory variables in the analysis. What the aggregate analysis points to is the net positive effect of trade liberalisation.

In the latter, empirical works examine the effect of trade policy through a productivity determinant equation in Thai manufacturing. They include Jongwanich and Kohpaiboon (2017) and Kohpaiboon and Jongwanich (2019). Despite having slightly different research focuses, both studies examine the effect of trade protection on productivity. Trade protection measured by changes in the lagged effective rate of protection at the industry level is one of the explanatory variables among the others. Note that Kohpaiboon and Jongwanich (2019) is a panel data analysis (from 2006 to 2016), whereas Jongwanich and Kohpaiboon (2017) is cross-sectional (using the 2011 industrial census). Both found empirical support for the positive effect of trade liberalisation on productivity.

There are two important findings from these studies. First, Jongwanich and Kohpaiboon (2017) showed that input and output tariffs should be treated separately in examining their impact on productivity. Ceteris paribus, lowering input tariffs potentially has at least two opposite effects: it allows firms to benefit in several ways enhancing their productivity, while also discouraging their efforts to improve productivity due to the increased level of effective protection. This necessitates caution when pursuing trade policy reform in not lopsidedly focusing on input tariffs while leaving output tariffs untouched. Even though input and output tariffs work differently in promoting firms' productivity, any trade policy reform process should take both input and output tariffs into consideration in ensuring trade is actually liberalised.

Secondly, as argued in Kohpaiboon and Jongwanich (2019), the negative effect of trade protection on productivity is enlarged by the highly concentrated domestic market, as measured by the Hirschman Herfindahl concentration index. This seems to be in line with the experience of Thai automotive industries where we observe water-in tariff, where the effectiveness of tariff protection on domestic price is deteriorated as a consequence of competition among firms. 
Another empirical work is Kohpaiboon (2012b), which examined the import-asa-market-discipline hypothesis in Thai manufacturing. The key finding suggests that international trade can act as a market discipline. Nonetheless, the net discipline effect is not found in all kinds of imported goods that would have it. In fact, the study also highlights how participating in the global production network, as well as outward market orientation, could play a key role to promote efficient use of scarce resources.

Another branch of literature focuses on exporting firms themselves. This is due to exporting firms often exhibiting higher productivity than locally oriented ones. Exporting firms must improve their production efficiency to overcome higher trade barriers and face different consumer tastes and tougher competition in international markets. In addition, exporting makes firms aware of potential innovations taking place aboard and they may assimilate these in order to improve their position in foreign markets (Greenaway and Kneller, 2007).

Such a finding is also found in empirical research of productivity determinants in Thai manufacturing (e.g. Jongwanich and Kohpaiboon, 2008; Kohpaiboon, 2012a; Kohpaiboon and Jongwanich, 2019). The finding is robust, regardless of the studying periods, the nature of the data (cross-sectional and panel) and how productivity is measured. All of these studies employed standard productivity determinant equations where the measure is the dependent variable. In all studies, explanatory variables include both firm- and industry-specific variables. The latter includes trade policy, producer production concentration ratio, and the presence of MNEs. Labour productivity is employed in Jongwanich and Kohpaiboon (2008) and Kohpaiboon (2012a) due to the cross-sectional nature of the data. In Kohpaiboon and Jongwanich (2019), Levinsohn and Petrin total factor productivity is used in the panel regression analysis. Export zero-one dummy and export propensity ratio at the plant level are used as alternative measure of exporting firms. In theory, the causality between export and productivity remains debatable, as it can be either firms learning from exports, learning to export, or both. Given the nature of plant-level data available in Thailand, the hypotheses cannot be empirically tested. Higher productivity found in the exporting firm could be explained by the propensity to commit product development R\&D found in the inter-plant cross-sectional analysis in Jongwanich and Kohpaiboon (2015). This is to learn more about competing products and customer preference in the international market.

\subsection{Export performance}

Poor quality is one criticism made towards the export-led growth strategy Thailand has pursued since the mid-1980s. In particular, the claim is that Thailand is struggling to maintain competitiveness in labour-intensive manufacturing (World Bank, 2016). Interestingly, the claimed poor export quality does not seem to be consistent with actual export performance, as described below. Figure 7.5 reports the scatter plot between annual growth rate of GDP 


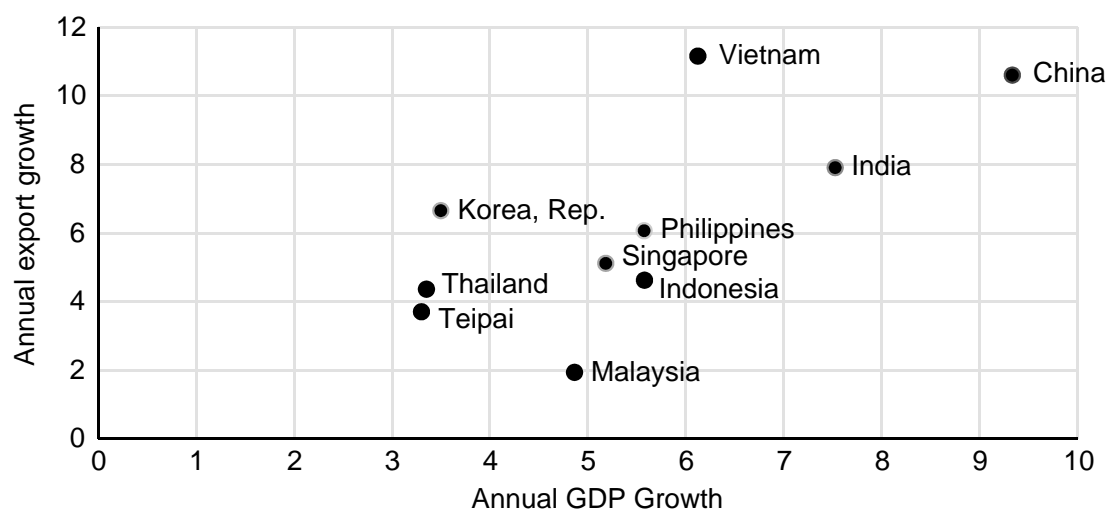

Figure 7.5 GDP-Export Nexus in Selected East Asian Economies between 2006 and 2016.

Source: World Development Indicator Database.

Note: GDP $=$ gross domestic product.

and exports of selected Asian countries averaging out between 2006 and 2016. The figure is the average from 2006 to 2016.

Thailand's annual growth was the lowest (the horizontal axis). It was not the export performance indicated by the position on the vertical axis. In addition, the simple and rather straightforward indicators like the successively increasing share of Thai manufacturing exports in the world for the past two decades cast some doubt on the claim above (Figure 7.6). In particular, the share of manufacturing exports from Thailand increased from $0.8 \%$ in 1992 to $1.4 \%$ in $2016 .{ }^{5}$

The recent study by Jongwanich (2019) examined the relationship between export diversification, export margins, and economic growth at the industry level using Thailand as a case study during 2002-16. The key finding is that the effects of export diversification and margins on economic growth vary across industries. In particular, export diversification helps to boost growth only in some sectors, including electronics, automotives, and chemicals, plastic, and rubber; while in the processed food, textile, and apparel industries, specialisation matters more in promoting growth. Such findings point to the danger of overemphasising extensive margins, especially in terms of new products, in promoting economic growth in developing countries like Thailand, where they still play an important role in many industries. ${ }^{6}$

One side effect of exports is the vulnerability of the economy to external shocks. This seems to be a trade-off. This was empirically examined in Cheewatrakoolpong and Manprasert (2014) through the case of the global financial crisis. Trade in East Asia is still largely linked to the US, regardless of its relative importance as an export destination. The explanation is the growing importance of GPS in the region. 


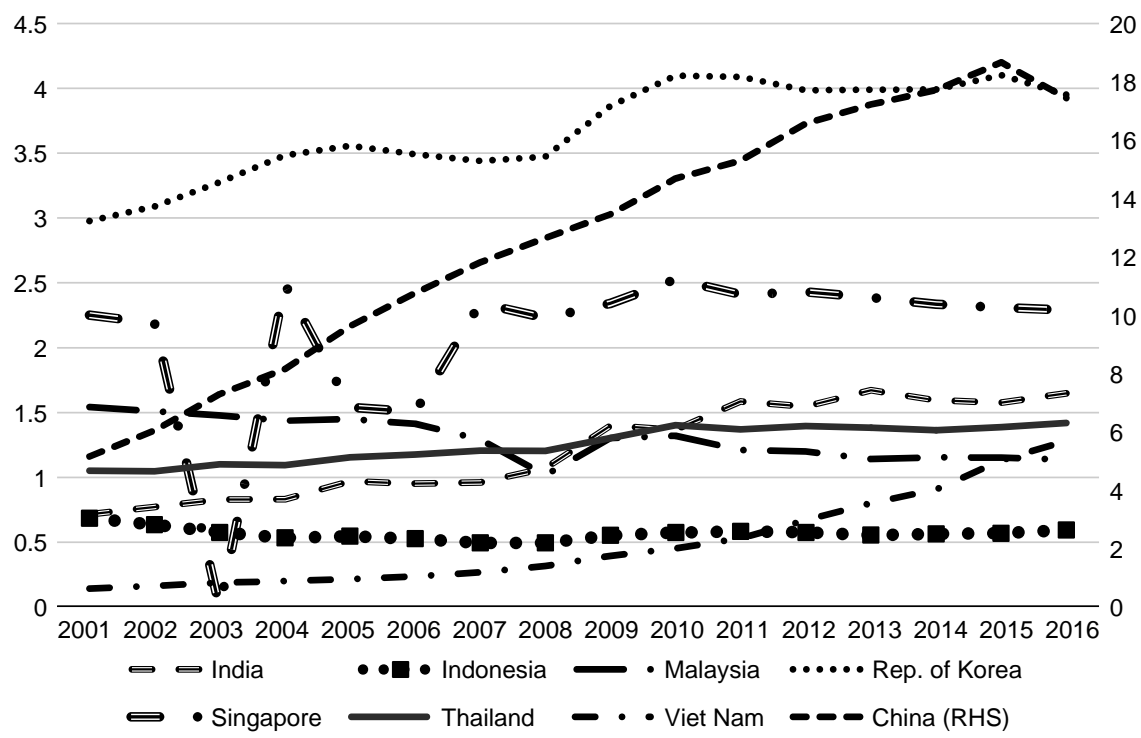

Figure 7.6 World Market Share of Manufacturing Products of Selected East Asia (\%). Source: UN Comtrade database.

1Note: Manufacturing product is defined as Standard International Trade Classification 5-8 net of 68 .

Another concern is about the job quality created by the export-led growth strategy adopted (Mounier and Charoenloet, 2010; Rasiah, Cheong, and Doner, 2014; and Charoenloet, 2015). In particular, Charoenloet (2015: 136) argued that many job opportunities created under an EOI strategy are sub-contracting, and vulnerable to being retrenched in the presence of negative shocks. Nonetheless, the relation between economic globalisation and low job quality in these studies is based on interpretation from various years of national socioeconomic surveys. It remains a wonder how the situation is taking place amid the rising real wage and the tightening labour markets. This points to the need for further research.

\subsection{Foreign divect investment and its spillovers}

The discussion above suggests that FDI plays an important role of global integration in Thailand. The entry of MNEs could affect the aggregate productivity of host investment-receiving countries. As MNEs are now widely regarded as the principle bearers of technology across international borders, their direct investment brings in not only capital but also production technology, managerial skills, international marketing channels and so on to host countries (Sjöholm, 1997; Borensztein, Gregorio, and Lee, 1998; Lipsey, 2000; Vernon, 2000). Their entry 
would be equivalent to adding highly productive firms and eventually affecting the overall productivity in host countries. This is widely known as the direct effect.

Indirectly, MNE presence could positively affect the productivity of locally non-affiliated firms in the host country. This is due to the fact that advanced technology that MNE affiliates bring with them could also generate a positive externality to the local firm. Technology is partially a public good in which owners cannot entirely prevent others from benefitting from it. Hence, locally non-affiliated firms could benefit to a certain extent MNE presence and experience productivity improvement. The positive externality is referred to as FDI/ MNE productivity spillover (Blomström and Kokko, 1998). Though not the only gain from FDI, spillover is often argued as the most desirable benefit.

FDI spillover, nonetheless, does not always exist, depending on the type of FDI inflows (e.g. efficiency and/or market seeking), or the economic and policy environments in host countries. ${ }^{7}$ Two factors are highlighted in the literature, namely absorptive capability and trade policy regime. Whether a local firm benefits from MNE presence depends on its knowledge-absorptive capability. The higher the absorptive capability, the greater the spillover the local firm in the host country can expect. Trade policy regime is another factor postulated in the literature. ${ }^{8}$ Productivity spillover tends to be smaller, or possibly even negative, under a restrictive, import substitution regime compared with a liberalising, export promotion regime, simply because different trade policy regimes entice different types of FDI inflows. As in Bhagwati's hypothesis, FDI inflows enticed by import substitution tend to be market-seeking and are invested mostly in the industries where proprietary assets are important. This creates barriers to entry for local firms and thus constrains productivity spillovers. In contrast, export promotion is more conducive to generating favourable spillover effects because, under such a regime, FDI is mostly attracted to industries in which the country has comparative advantage, i.e. efficiency-seeking FDI. In such industries, local firms have a greater potential to catch up with foreign firms and achieve productivity improvement. (Table 7.4)

Recently, the empirical studies of FDI spillover literature point to linkages and backward ones in particular as other potential channels that advance technology associated with MNE affiliates could benefit local non-affiliates. ${ }^{9}$ Spillovers through linkage channels are often referred to as vertical FDI, whereas the spillover mentioned above is horizontal. Many empirical works prefer vertical FDI spillovers because there would be mutual benefit that MNE affiliates and local suppliers can share. This is different from what we expect from the horizontal FDI spillovers, where MNEs would have an incentive to prevent information leakage to their competitors, including local enterprises, thereby reducing the possibility of the spillover taking place (Javorcik, 2004).

One consensus in the empirical research about the presence of MNEs in Thai manufacturing is that MNE affiliates are likely to be more productive than indigenous ones. ${ }^{10}$ This finding is insensitive to model specification (trans-log vs. Cobb-Douglas production function), as well as the measure of productivity (total factor productivity vs. labour productivity). Interestingly, a finding 
Economic consequences of globalisation 181

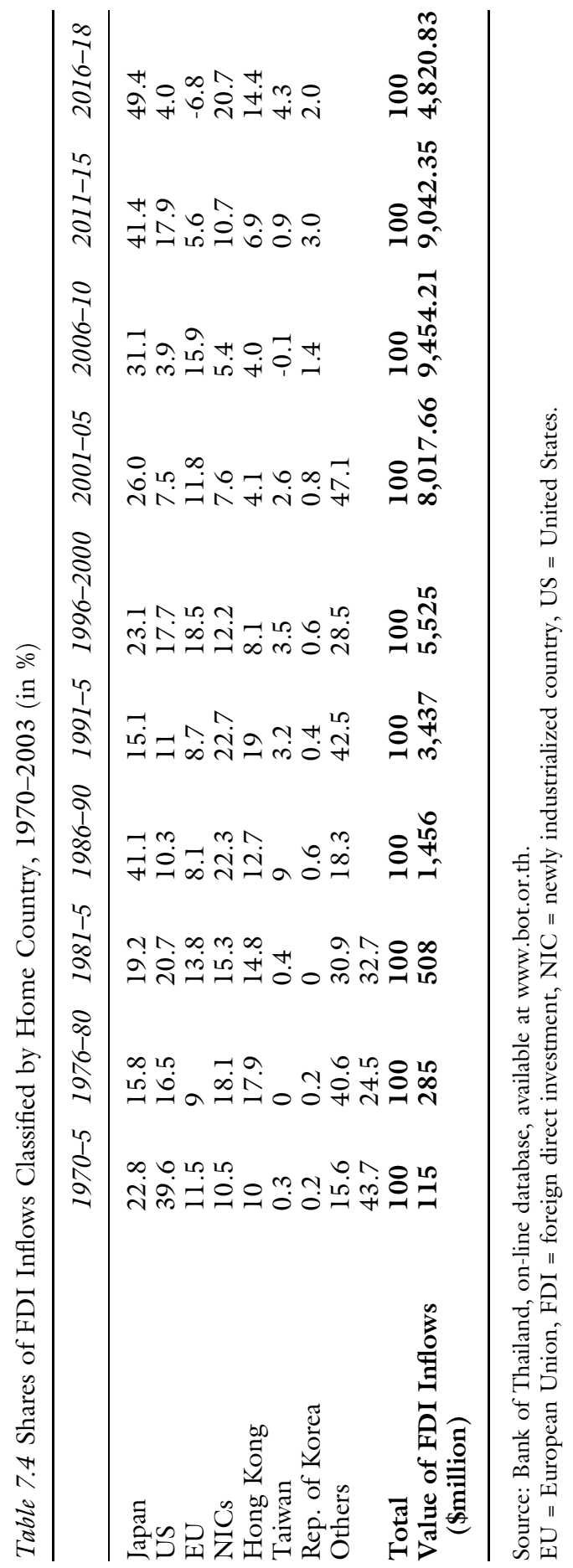




\section{2}

revealed in Jongwanich and Kohpaiboon (2015) is that MNE affiliates are less likely to commit to R\&D investment. This is especially true for production technology and product development. Nonetheless, an MNE presence could affect $R \& D$ propensity and intensity of locally non-affiliated firms to do $R \& D$, leading to product development and process innovation.

It is the MNE technology spillover that varies across industries. So far there are four systematic analyses examining FDI spillovers in Thai manufacturing, i.e. Kohpaiboon (2006), Kohpaiboon (2012a), Wongseree (2012), and Tantratananuwat (2015). Each of these uses different sets of plant-level data. Kohpaiboon (2006) uses the 1996 industrial census and undertook the cross-sectional inter-industry analysis (i.e. fourdigit ISIC), whereas Kohpaiboon (2012a) and Wongseree (2012) are the panel data econometric analysis at the plant level, using the survey information by Office of Industrial Economics, Ministry of Industry. Note that Kohpaiboon (2012a) employs the panel data between 2001 and 2003, whereas Wongseree's 2012 analysis is based on that between 2001 and 2006. As documented in Kohpaiboon (2012a), the data quality of the survey noticeably deteriorated after 2004. Analysis in Tantratananuwat (2015) is plant-level cross-sectional, using the 2006 industrial census of Thai manufacturing. Only Kohpaiboon (2012a), Wongseree (2012), and Tantratananuwat (2015) examined both horizontal and vertical spillovers together. Kohpaiboon (2006) focused solely on horizontal spillovers.

The key finding from all studies but Wongseree (2012) nonetheless supports the role of trade policy. That is, advanced technology associated with MNE affiliates does not always spill over to the local plants operating in the same industry. The extent of spillovers depends on the nature of the trade policy regime. Only industries operating under a liberal trade policy regime experience positive horizontal FDI spillovers. Vertical FDI spillovers are found only when an assumption of identical horizontal ones is in place, as indicated in Kohpaiboon (2012a), Wongseree (2012), and Tantratananuwat (2015). This is what has been done in the existing literature (e.g. Javorcik, 2004; and Blalock and Gertler, 2008). When such an assumption is relaxed, as performed by Kohpaiboon (2012a) and Tantratananuwat (2015), neither backward nor forward spillovers are found.

This finding is important amid the growing protectionism sentiment. In particular, policymakers in many countries overclaimed the finding of spillovers through backward linkages and tried to pursue policy-induced linkages like local content requirements towards MNEs. As revealed in Kohpaiboon (2015) and Hill and Kohpaiboon (2017) through an in-depth case study of Thai automotive development, the conducive role of the backward linkage channel mentioned in the literature is a result of natural links that are driven by economic concerns and can be distorted by policy measures. The ability of the policy domain to forge linkages seems to be limited. Policy-induced linkages are not perfect substitutes for natural linkages. The magnitude of linkages is not a good proxy of the magnitude of vertical FDI spillovers. It is better to be measured by the quality of backward linkages, where actual participation between upstream and downstream firms is intensive based on common interest. Where quality is concerned, backward linkages driven by economic concerns, as well as 
motivated by capability of indigenous suppliers, are by far superior to those induced by policy measures.

In addition to productivity spillovers, two additional types were examined empirically in Thai manufacturing. They are those where MNE presence affects firms' decision to export and to commit to $R \& D$, respectively. In particular, Jongwanich and Kohpaiboon (2008) ${ }^{11}$ and Jongwanich and Kohpaiboon (2015) found evidence supporting a favourable effect of MNE presence on decision to export and R\&D investment, respectively.

\subsection{Upgrading}

Upgrading plays a crucial role in promoting medium-to-long-term economic growth, as well as sustainable economic development. Nonetheless, prospects of a firm upgrading are related to at least two drivers of economic globalisation, i.e. labour mobility and trade, each of which is relevant for Thailand.

\section{Labour mobility}

As mentioned earlier, the labour market tightening and a continued increase in (real) wages since the new millennium resulted in an increase in unskilled foreign workers from neighbouring countries in mainland Southeast Asia in Thailand. The official estimates of these workers reached 2 million by 2017, but these far underestimated the actual totals. Thai governments have expressed a reluctance to allow an inflow of workers, unskilled labourers in particular, despite the demand from entrepreneurs. Among numerous social and economic consequences resulting from the import of unskilled foreign workers, one relates to the possible negative effects on the structural adjustment processes of organisations. In particular, when firms are allowed to hire unskilled foreign workers to support structural adjustment, they may eventually become reliant on them. Subsequently, their investments and other decisions could be made on the premise that labour costs will continue to be held down by migration. As a result, firms will remain at the low end of the value chain and rely on low wages as a key factor in competing on the world market. This would eventually retard upgrading.

Kohpaiboon, Jongwanich, and Kulthanavit (2012) undertook a systematic analysis using the Thai clothing industry as a case study. The analysis is based on in-depth interviews with 50 clothing firms in Thailand during November 2009-February 2010. This issue was revisited in Kohpaiboon and Jongwanich (2017), where a questionnaires approach was conducted during October-December 2015. Three sets of questionnaires were developed to address stakeholders, including 25 firms, 120 local workers, and 186 foreign workers. The point to be revisited is due to the changing situation in both labour-importing and -exporting countries. In the former, the policy stance of the Thai government has adjusted to managing, rather than preventing, the flow of these workers. Economic progress during 2010-15 in the latter countries, such as Cambodia, Lao People's Democratic Republic, and Myanmar, encouraged 


\section{Archanun Kohpaiboon \& Juthathip Jongwanich}

some foreign workers to return home to benefit from the increasing job opportunities at home. This may have been supported by an influx of FDI into the labour-exporting countries, especially Myanmar.

The key finding is that not all firms opt to hire unskilled foreign workers. All firms in both Kohpaiboon, Jongwanich, and Kulthanavit (2012) and Kohpaiboon and Jongwanich (2017) agreed in the interviews that they opted to employ foreign workers to keep their operations running smoothly, although this option incurs costs and uncertainty. Interestingly, firms employing foreign workers also used other options, such as improving productivity, exporting capital, and capital deepening (using capital to substitute for workers) to cope with labour shortages, indicating that they are not mutually exclusive and firms can use any or all of them to maintain performance.

There is no evidence of a causal relationship to indicate that employing foreign workers retards firms' productivity. Rather, we found the opposite. It is the wellperforming firms that are in a better position to attract foreign workers and maintain production capacity. Struggling firms are less likely to be able to compete for, and therefore benefit from, foreign workers to enhance their capacity. The differences in company characteristics between firms that hire foreign workers and those that do not are clear. Between 2009 and 2010, those hiring unskilled foreign workers were likely to be relatively small, both in terms of employees and sales, and were typically struggling to maintain their profit margins; hence, they did not adequately invest in upgrading activities (Kohpaiboon, Jongwanich, and Kulthanavit, 2012). The situation slightly changed in 2015, when large firms started to compete with medium-sized firms for foreign workers (Kohpaiboon and Jongwanich, 2017).

The chance to access unskilled foreign workers at lower wages would not significantly deter process-based upgrading. The decision to employ foreign workers depends on other factors, such as policy uncertainty and the associated management problems, such as communication and worker cohesion, compared with the benefits of maintaining the production capacity. Upgrading decisions are largely influenced by global competition and multinational firms that govern production networks in particular.

The finding above is in line with that in Sriudomkajorn (2016), who examined the wage impact of these unskilled foreign workers. In particular, the growth of (real) wages in Thai manufacturing continued, even though there was an influx of foreign workers. Both an industrial census and a socio-economic survey were employed in Thailand to test the impact.

\section{Participating in global production sharing (GPS)}

As illustrated above, Thailand has long been engaged in GPS via MNEs. One undesirable consequence of GPS for developing countries is that as production processes are divided into separate stages and economically allocated, and relatively unskilled labour-intensive activities may be moved to developing countries in line with their comparative advantage, this would increase demand for 
unskilled workers as opposed to skilled ones. As a result, the wage gap between unskilled and skilled workers would tend to contract and it is likely for developing countries to be trapped into low-end segments of value chains. In other words, the prospect is bleak for developing countries' firms.

Nonetheless, the discussion above is carried out under the implicit assumption that there is a single production cone where there is no factor intensity reversal and firms in developed and developing countries face the same factor endowment vector. In reality, a number of studies point to such an assumption being rather restrictive (Leamer and Levinsohn, 1995; Feenstra, 2004; Leamer and Schott, 2005; Kiyota, 2012). Therefore, unskilled labour-intensive activities outsourced by firms in developed countries might require relatively skilled workers in developing countries for these activities to be performed. Therefore, it is possible that demand for skilled to unskilled workers increases in both developing and developed countries simultaneously, so that a wage gap persists as a result of GPS.

Empirical studies by Chongvilaivan and Thangavelu (2012), Kohpaiboon and Jongwanich (2014), and Kohpaiboon (2019) study this issue. Chongvilaivan and Thangavelu (2012) did not address the role of GPS itself; instead, outsourcing in their study is defined loosely as the arrangements whereby the physical and/or human resources related to a firm's production factors are administrated by outside providers. In Kohpaiboon and Jongwanich (2014), the issue was addressed through the effect of GPS on wage premiums, defined as the wage gap between unskilled and skilled workers using an inter-plant, cross-sectional 2011 industrial census of Thai manufacturing. In addition to plant- and industryspecific variables, the extent to which an industry participates in GPS is introduced as the explanatory variable to test the hypothesis.

In Kohpaiboon (2019), three industrial censuses of Thai manufacturing between 2006 and 2016 are used to perform the panel econometrics. In the analysis, the decision to hire workers is examined, i.e. how many blue-collar workers are hired, and their relative importance vis-à-vis total workers (a sum of whiteand blue-collar workers). The extent to which an industry participates in the GPS is introduced to examine the effect on skill formation.

Despite differences in various aspects across these three studies, each points to the fact that the outsourced labour-intensive activities do not necessarily imply unskilled worker activities to developing countries. Evidence from Thai manufacturing supports developing countries opening up to international trade and participating in GPS. Mutual benefits from participating in the global production network remain to be shared between developed and developing countries.

Interestingly, in Kohpaiboon (2019), one interesting finding is that plants in GPS-intensive industries are likely to hire skilled workers all other things being equal. It does not mean that they tend to hire fewer unskilled ones; in fact, both unskilled and skilled workers complement each other. This would have an immense policy implication in managing flows of unskilled workers from neighbouring countries. 


\section{Conclusion and policy lessons}

The paper reviews empirical works examining the effect of globalisation in Thailand. It begins with a policy discussion and how Thai economy is integrating into the global economy. Three drivers of economic globalisation are emphasised, i.e. international trade, foreign direct investment and cross-border labour mobility. The 2016 World Bank diagnostic report is used to address the current criticism made of globalisation's economic consequences.

The finding in the empirical studies points to globalisation and its potential to create favourable impacts on economic development. Opening up to international trade could promote Thai productivity and drive economic growth. Export-oriented firms exhibit higher productivity as opposed to locally oriented ones, and are more likely to invest in R\&D and develop products. Export performance cannot be a source of the growth slowdown in Thailand since 2005. FDI inflows enticed by EOI strategies are large and likely to generate horizontal technological spillovers from foreign affiliates to indigenous ones within a given industry. The presence of vertical spillovers through the linkages was not a robust result. This is especially so in cases where the horizontal spillover is different across industries, instead of assuming it occurs homogenously.

Firms opted to employ foreign workers to keep their operations running smoothly, although this option incurs costs and uncertainty. There is no evidence of a causal relationship to indicate that employing foreign workers retards firms' productivity. Rather, we found the opposite. It is the well-performing firms that are in a better position to attract foreign workers and maintain production capacity. The chance to access unskilled foreign workers at lower wages would not significantly deter the decision to undertake upgrading, which is largely influenced by global competition and multinational firms that govern production networks in particular.

Participating in GPS does not necessarily mean the participating countries are trapped into the low end of the quality ladder. In fact, evidence from Thai manufacturing suggests the outsourced labour-intensive activities are not the unskilled-worker activities to developing countries. Even though plants in GPSintensive industries are likely to hire skilled workers, all other things being equal, it does not mean that they tend to hire fewer unskilled ones. In fact, both unskilled and skilled workers complement each other.

Three policy lessons can be drawn from this paper. First, the Thai experience points to globalisation and its potential to create favourable economic impacts. This argues for further accelerating Thailand's push to be globally integrated. This is especially true for trade policy, which remains unfinished business in many developing countries. Such policy reluctance could retard productivity improvement.

Second, there are side effects as a consequence of globalisation, including economic vulnerability to external shocks and the possibility of creating inferior jobs by the export-led growth strategy outsourced. However, these can be mitigated by other policies such as strengthening the social safety net instead of deterring progress in economic globalisation. 
Third, it seems that participating in GPS plays an important role in the global integration of Thailand due to the presence of mutual benefits shared between developed and developing countries. The outlook of GPS remains uncertain due to several structural changes in the world economy, some promoting it while others do not. The net effect is largely unknown, but unlikely to take place in disruptive manner. Hence, this would be another upcoming challenge for policymakers in Thailand, as well as other GPS participating countries to keep eye on it.

\section{Notes}

1 Henceforth, economic globalisation is at the centre of the following discussion and is referred to as globalisation for brevity.

2 Under the Thai-US Treaty of Amity and Economic Relations signed in 1966, US companies in Thailand are granted equal treatment to Thai companies. This permits $100 \%$ of US-owned companies to operate in sectors where other foreign companies are generally allowed a maximum ownership level of $49 \%$. In addition, US companies are allowed to own land up to 10 rai, or 0.16 hectares, with an approval from the Ministry of Interior. The Land Code (1954) was amended in 1999 to relax this restriction. Since 1999, foreign investors regardless of nationality have been able to own up to four rai of land for residential purposes.

3 Arguably, the World Trade Organization (WTO) notification about NTMs might be underestimated due to underreporting. Based on the comprehensive database on NTMs from the United Nations Conference on Trade and Development's global database at trains.unctad.org., Ing, de Cordoba, and Cadot. (2016) suggested the opposite outcome. This is clearly beyond the current scope of this paper, but important to further research topics.

4 See cross-sectional, inter-country empirical evidence in Balasubramanyam, Salisu, and Sapsford (1996).

5 Interestingly, when focusing only on developing countries, the slightly declining trend of Thailand's manufacturing export share was observed from 2000 to 2014 . In particular, the share dropped from $3.6 \%$ in 2000 to $2.9 \%$ in 2014. Note that this seems to be a common trend amongst developing East Asia as a result of the rapid expansion of manufacturing exports from China and Vietnam. Nonetheless, the declining trend of Thai manufacturing is less when compared to other developing East Asia economies. Data are available upon request.

6 Extensive margin refers to a situation where a country exports to new destinations, new products, or both, whereas intensive margin is that where a country exports the same product to the export destination.

7 See the recent survey in Crespo and Fontoura (2007).

8 See a comprehensive review about the role of trade policy in conditioning on gains from FDI in Kohpaiboon (2006).

9 See, for example, Rodríguez-Clare (1996), Markusen and Venables (1999), Javorcik (2004), Lin and Saggi (2004), Blalock and Gertler (2008).

10 For example, see Kohpaiboon and Jongwanich (2019).

11 Jongwanich and Kohpaiboon (2008) employed the 1996 industrial census, whereas Jongwanich and Kohpaiboon's 2012 analysis is based on the 2006 industrial census. Estimation in the former is based the limited dependent variable technique (i.e. Logit and Probit estimation). In the latter, Heckman's two steps were used. 


\section{References}

Balasubramanyam, V.N., M.A. Salisu, and D. Sapsford (1996), 'Foreign Direct Investment and Growth in EP and IS Countries', Economic Journal, 106 (434), 92-105.

Bhagwati, J . (2004), In Defense of Globalization. New York: Oxford University Press.

Bisonyabut, N. and C. Kamsaeng (2015), Local Innovation Vital to Sustain Growth. Bangkok: TDRI Insight. Tdri.or.th/en/tdri-insight/local-innovation-vital-tosustain-growth

Blalock, G. and P.J. Gertler (2008), 'Welfare Gains from Foreign Direct Investment through Technology Transfer to Local Suppliers', Journal of International Economics, 74(2), pp.402-421.

Blomström, M. and A. Kokko (1998), 'Multinational Corporations and Spillovers', Journal of Economic Surveys, 12, pp.247-277.

Borensztein, E., J.D. Gregorio, and J.W. Lee (1998), 'How Does Foreign Direct Investment Affect Economic Growth?', Journal of International Economics, 45(1), pp.115-135.

Bylander, M. and G. Reid (2017), 'Criminalizing Irregular Migrant Labor: Thailand's Crackdown in Context', Migration Information Source, October. https:// www.migrationpolicy.org/article/criminalizing-irregular-migrant-labor-thailands-crackdown-context

Charoenloet, V. (2015), 'Industrialization, Globalization and Labour Force Participation in Thailand', Journal of the Asia Pacific Economy, 20(1), pp.130-142.

Cheewatrakoolpong, K. and S. Manprasert (2014), 'Trade Linkages and Crisis Spillover', Asian Economic Paper, 13(1), pp.84-103.

Chongvilaivan, A. and S.M. Thangavelu (2012), 'Does Outsourcing Provision Lead to Wage Inequality? New Evidence from Thailand's Establishment-level Data', Review of International Economics, 20(2), pp.364-376.

Crespo, N. and M.P. Fontoura (2007), 'Determinant Factors of FDI Spillovers: What Do We Really Know?', World Development, 35(3), pp.410-425.

Diao, X., J. Rattso, and H. Stokke (2006), 'Learning by Exporting and Structural Change: A Ramsey Growth Model of Thailand', Journal of Policy Modeling, 28, pp.293-306.

Feenstra, R. (2004), Advanced International Trade: Theory and Evidence. Princeton, NJ: Princeton University Press.

Greenaway, D. and R. Kneller (2007), 'Firm Heterogeneity, Exporting and Foreign Direct Investment', Economic Journal, 117(517), pp.134-161.

Hill, H. and A. Kohpaiboon (2017), 'Policies for Industrial Progress, Not Industry Policy: Lessons from Southeast Asia', in L.Y. Ing and F. Kimura (eds.), Production Networks in Southeast Asia. New York, NY: Routledge, pp.202-224.

Ing, L., S. de Cordoba, and O. Cadot (2016), Non-Tariff Measures in ASEAN, United Nations Conference on Trade and Development (UNCTAD) and Economic Research Institute for ASEAN and East Asia, Jakarta.

Irwin, D. (2015), Free Trade Under Fire (4th edition). Princeton, NJ: Princeton University Press.

Javorcik, B.S. (2004), 'Does Foreign Direct Investment Increase the Productivity of Domestic Firms? In Search of Spillovers through Backward Linkages', American Economic Review, 94(3), pp.605-627. 
Jitsuchon, S. (2012), 'Thailand in a Middle-income Trap', TDRI Quarterly Review, 27(2), pp.13-20.

Jongwanich, J. (2007). Capital Mobility, Exchange Rate Regimes, and Currency Crisis. New York: Nova Science.

Jongwanich, J. (2019), 'Export Diversification, Margins and Economic Growth at Industrial Level: Evidence from Thailand', Presentation at Transforming Economies - For Better Jobs UNU-WIDER Development Conference in partnership with UNESCAP, 11 September, Bangkok.

Jongwanich, J., \& A. Kohpaiboon (2007). 'Determinants of Protection in Thai Manufacturing,' Economic Papers, 26(3), 276-94.

Jongwanich, J. and A. Kohpaiboon (2015), 'Multinational Enterprises, Exporting and R\&D Activities in the South', Thailand and the World Economy (Formerly Thammasat Economic Journal), 33(2), pp.1-54.

Jongwanich, J. and A. Kohpaiboon (2017), 'Trade Protection and Firm Productivity: Evidence from Thai Manufacturing', Developing Economies, 55(2), pp.130-157.

Kiyota, K. (2012), 'A Many-cone World?', Journal of International Economics, 86(2), pp.345-354.

Kohpaiboon, A. (2003), 'Foreign Trade Regime and FDI-growth Nexus: A Case Study of Thailand', Journal of Development Studies, 40(2), pp.55-69.

Kohpaiboon, A. (2006a), 2006a. Multinational Enterprises and Industrial Transformation: Evidence from Thailand, Cheltenham: Edward Elgar.

Kohpaiboon, A. (2006b), 'Foreign Direct Investment and Technology Spillover: A Cross-industry Analysis of Thai Manufacturing', World Development, 34(3), pp.54l-556.

Kohpaiboon, A. (2008), 'Multinational Enterprises and Export of the Developing Country: Analysis of Thai Manufacturing', Thailand and the World Economy (Formerly Thammasat Economic Journal), 26(3), pp.1-40.

Kohpaiboon, A. (2012a), 'Vertical and Horizontal FDI Technology Spillovers: Evidence from Thai Manufacturing', in S. Urata, C. Hahn, and D. Narjoko (eds.), Economic Consequences of Globalization: Evidence from East Asia. New York: Routledge-ERIA Studies in Development Economics, pp.148-168.

Kohpaiboon, A. (2012b), 'Imports-as-Market-Discipline Hypothesis: Evidence from the Thai Manufacturing Sector', in S. Urata, C. Hahn, and D. Narjoko (eds.), Economic Consequences of Globalization: Evidence from East Asia. New York: Routledge-ERIA Studies in Development Economics, pp.190-212.

Kohpaiboon, A. (2015). FTAs and Supply Chains in the Thai Automotive Industry in ASEAN and Regional Free Agreements. edited by C. Findlay, Routledge, pp. 229-255.

Kohpaiboon, A. (2019), 'Hiring Skill Workers in Global Production Sharing: Evidence of Thai Manufacturing Plants', Policy Report submitted to Human Resource Institute, Thammasat University, Bangkok.

Kohpaiboon, A.(2020). 'Industrial 4.0 of Thailand', ISEAS Policy Brief, Singapore. Kohpaiboon, A. and J. Jongwanich (2013), 'International Production Network, Clusters and Industrial Upgrading: Evidence from Automotive and Hard Disk Drive Industries', Review of Policy Research, 30(2), pp.211-239.

Kohpaiboon, A. and J. Jongwanich (2014), 'Global Production Sharing and Wage Premiums: Evidence from the Thai Manufacturing Sector', Asian Development Review, 31(2), pp.141-164. 
Kohpaiboon, A. and J. Jongwanich (2017), 'Structural Adjustment and International Migration in the Thai Garment Industry: Re-visit', in Rethinking Migration Governance in the Mekong Region: From the Prospective of the Migrant Workers and Their Employers. ERIA Research Project Report No.19, Jakarta. http:// www.eria.org/uploads/media/FullReport_RPR_FY2017_19.pdf

Kohpaiboon, A. and J. Jongwanich (2019a), 'Effectiveness of Industrial Policy on Firm's Productivity: Evidence of Thai Manufacturing', Research submitted to Economic Research Institute of ASEAN and East Asia (ERIA), Jakarta.

Kohpaiboon, A. and J. Jongwanich (2019b), 'The Use of FTAs: the Thai Experience', in L.Y. Ing, M. Richardson, and S. Urata (eds.), East Asian Integration: Goods, Services and Investment. New York: Routledge, pp.114-142.

Kohpaiboon, A., J. Jongwanich, and P. Kulthanavit, (2012), 'Structural Adjustment and International Migration: An Analysis of the Thai Clothing Industry', Oxford Development Studies, 40(2), pp.231-260.

Krueger, A.O. (1992), Economic Policy Reforms in Developing Countries. Oxford, United Kingdom: Basil Blackwell.

Krugman, P. (1995), 'Growing World Trade: Causes and Consequences', Brookings Papers on Economic Activity, 25th Anniversary Volume, Vol. 26, pp.327-377.

Krugman, P. (2000). 'Fire-sale FDI,' in E. Sebastian (ed). Capital Flows and the Emerging Economies: Theory, Evidence, and Controversies, Chicago: University of Chicago Press, pp. 43-58.

Leamer, E. and J. Levinsohn (1995), 'International Trade Theory: The Evidence', in G. Grossman and K. Rogoff (eds.), Handbook of International Economics Vol. 3. Amsterdam: Elsevier.

Leamer, E. and P. Schott (2005), 'The Rich (and Poor) Keep Getting Richer', Harvard Business Review, 83(4), p.20.

Lin, P. and K. Saggi (2004), 'Multinational Firms, Exclusivity, and the Degree of Backward Linkages', Kiel Institute for the World Economy (IFW) Working Papers 1250. Kiel: IFW.

Lipsey, R.E. (2000), 'Inward FDI and Economic Growth in Developing Countries', Transnational Corporations, 9(1), pp.67-95.

Markusen, J. and A. Venables (1999), 'Foreign Direct Investment as a Catalyst for Industrial Development', European Economic Review, 43, pp.335-356.

Melitz, M.J. (2003), 'The Impact of Trade on Intra-Industry Reallocations and Aggregate Industry Productivity', Econometrica, 71(6), pp.1695-1725.

Mounier, A. and V. Charoenloet (2010), 'New Challenges for Thailand: Labour and Growth after the Crisis', Journal of Contemporary Asia, 40(1), pp.123-143.

Phoonichaisuk, A. (2010), 'FDI-Growth Nexus: Evidence of Thailand', MA Thesis, Faculty of Economics, Thammasat University.

Private Investment Promotion Working Group (2015), '10 Target Industries: New Engine of Growth', Report submitted to Prime Minister, 17 November. https:// thaipublica.org/wp-content/uploads/2015/11/BOI_kanit.pdf (in Thai).

Rasiah, R., K.C. Cheong, and R. Doner (2014), 'The Southeast Asian Experience with the Asian and Global Financial Crises', Journal of Contemporary Asia, 44(4), pp.572-580.

Rodríguez-Clare, A. (1996), 'Multinationals, Linkages, and Economic Development', American Economic Review, 86(4), pp.852-873.

Sachs, J. and A. Warner (1995), 'Economic Reform and the Process of Global Integration', Brookings Papers on Economic Activity, 1(25th Anniversary), pp.1-95. 
Sjöholm, F. (1997), 'R\&DD, International Spillovers and Productivity Growth', Lund Economics Studies, No. 63. Lund: Lund University.

Sriudomkajorn, P. (2016), 'Foreign Workers in Thai Manufacturing: Trends, Patterns, and Implications for Domestic Wages', MA Thesis, Thammasat University, Bangkok.

Suehiro, A. (1989), Capital Accumulation in Thailand, 1855-1985. UNESCO. Tokyo: The Center for East Asian Cultural Studies.

Tangkitvanich, S. and N. Bisonyabut (2015), 'Toward High-Quality Growth: Thailand's Challenges and Opportunities in the Next Three Decades', TDRI Quarterly Review, 30(1, March ), pp.3-15.

Tantratananuwat, P. (2015), 'Vertical and Horizontal FDI Technology Spillovers in Thai Manufacturing: Does Measurement Matter?', MA Thesis, Thammasat University, Bangkok.

Urata, S. and K. Yokota (1994), 'Trade Liberalization and Productivity Growth in Thailand', Developing Economies, 32(4), pp.444-459.

Vernon, R. (2000), In the Hurricane's Eye: The Troubled Prospects of Multinational Enterprises. Cambridge: MIT Press.

Warr, P. (2011), 'A Nation Caught in the Middle-Income Trap', East Asia Forum Quarterly, (October-December), pp.4-6. https://www.eastasiaforum.org/2 $011 / 12 / 18 /$ thailand-a-nation-caught-in-the-middle-income-trap/

Warr, P.G. and B. Nidhiprabha (1996), Thailand's Macroeconomic Miracle: Stable Adjustment and Sustained Growth. Kuala Lumpur: Oxford University Press.

Wells, L.T. Jr. (1986), 'Investment Incentives: An Unnecessary Debate', TNC Reporter, 22(Autumn), pp.12-16.

Wolf, M. (2005), Why Globalization Works. New Haven: Yale University Press.

Wongseree, S. (2012), 'Foreign Direct Investment and Local Firm Productivity: Evidence from Thailand', Doctoral Dissertation, University of Tennessee, Knoxville.

World Bank (2014), Preserving Stability and Promoting Growth. Washington, DC: World Bank. http://documents.worldbank.org/curated/en/256651468248662652/pdf/ East-Asia-Pacific-economic-update-April-2014-preserving-stability-and-promotinggrowth.pdf

World Bank (2016), 'Thailand: Getting Back on Track: Reviving Growth and Securing Prosperity for All (A Systematic Country Diagnostic), November 10.

World Trade Organization (WTO) (2015), Trade Policy Review - Thailand. Geneva, Switzerland: WTO. 